\title{
The Occurrence of Aflatoxins in Date Palm (Phoenix dactylifera L.) Worldwide
}

\author{
Merfat Abdulrahman Almaghrabi (D) \\ Food and Nutrition Department, King Abdulaziz University, P.O. Box 80200, Jeddah 21589, Saudi Arabia \\ Correspondence should be addressed to Merfat Abdulrahman Almaghrabi; mamaghrabi@kau.edu.sa
}

Received 30 November 2021; Revised 15 January 2022; Accepted 9 February 2022; Published 7 March 2022

Academic Editor: Yunpeng Cao

Copyright (c) 2022 Merfat Abdulrahman Almaghrabi. This is an open access article distributed under the Creative Commons Attribution License, which permits unrestricted use, distribution, and reproduction in any medium, provided the original work is properly cited.

\begin{abstract}
Due to global warming, the risk of aflatoxins exposure through the consumption of contaminated food has increased. Aflatoxins pose serious health hazards to humans' and animals' health because of their carcinogenic, mutagenic, and teratogenic properties and their immunosuppressive effects. Aflatoxin contamination in various agricultural commodities has attracted much attention worldwide. Date palm fruits are among these important commodities that are vulnerable to fungal contamination and consequent aflatoxins production. Furthermore, dates are often consumed directly without any further processing, which may result in direct exposure to aflatoxins. Moreover, dates are the second dried fruits traded worldwide, which reflects the widespread consumption of dates due to their nutritive values in addition to religious and cultural values. Accordingly, this review summarizes and discusses the frequency and incidence of aflatoxin contamination in dates worldwide and outlines the analytical procedure for aflatoxin determination in dates for the first time. The susceptibility of date palm fruits to aflatoxins contamination has been documented at various levels in several regions. The findings urged the importance of conducting more comprehensive studies on aflatoxin occurrence and contamination levels in dates as a likely contributor to the dietary exposure to aflatoxins.
\end{abstract}

\section{Introduction}

Food security and the potential effects of global warming on crops have become crucial aspects worldwide [1]. Global warming has increased the risk of mycotoxin exposure as the Earth's temperature has increased; water evaporation from the Earth's surface has increased as well, resulting in escalating humidity and spreading the risk of mycotoxigenic Aspergillus species. Consequently, these climatic changes have increased the production of mycotoxins, such as aflatoxins, which are among the most hazardous mycotoxins $[2,3]$.

More than 20 forms of aflatoxins exist. However, aflatoxin $B_{1}\left(A_{F B}\right)$, aflatoxin $B_{2}\left(A_{F B}\right)$, aflatoxin $G_{1}\left(A F G_{1}\right)$, and aflatoxin $\mathrm{G}_{2}\left(\mathrm{AFG}_{2}\right)$ are considered the most common and important types of aflatoxins [4]. These toxins contaminate various agricultural commodities, such as nuts, spices, cereals, and dried fruits $[5,6]$. A recent risk assessment of aflatoxins in food published by the European
Food Safety Authority (EFSA), which assessed the toxicity of aflatoxins and subsequently their health risks to humans, reported that, among all types of aflatoxins, $\mathrm{AFB}_{1}$ was the most frequent contaminant detected in food, and it is not appropriate to establish a tolerable daily intake (TDI) for aflatoxins [7]. This is because aflatoxins pose a risk to human and animal health due to their carcinogenic, mutagenic, and teratogenic properties and immunosuppressive effects [7-9]. The consequences of low-dose exposure over a long period of time or high-dose exposure over a short time include chronic toxicity or acute toxicity and death, respectively, in humans [10]. The primary target organ of aflatoxin is the liver, and aflatoxin can be metabolised by the cytochrome P450 (CYP) enzyme system. The CYP enzymes convert $\mathrm{AFB}_{1}, \mathrm{AFG}_{1}$, and $\mathrm{AFM}_{1}$ to their respective epoxides, which can bind covalently to both DNA and proteins. In particular, aflatoxin epoxide can bind rapidly to the $\mathrm{N}-7$ position of guanine in DNA to form $\mathrm{AFB}_{1}-\mathrm{N} 7$-guanine adducts, which are mutagenic if not repaired, while aflatoxin epoxide in liver 
cells and aflatoxin dialdehyde in blood can bind covalently to lysine in albumin to form aflatoxin albumin adducts [11]. The International Agency for Research on Cancer (IARC) lists $\mathrm{AFB}_{1}, \mathrm{AFB}_{2}, \mathrm{AFG}_{1}, \mathrm{AFG}_{2}$, and $\mathrm{AFM}_{1}$ as Group 1 carcinogens based on strong evidence of their genotoxicity being involved in the formation of DNA adducts causing point mutations in the TP53 gene [12]. The EFSA emphasises the importance of continuously monitoring the occurrence of aflatoxins due to the Earth's changing climate and its impact on increases in the risk of aflatoxins contamination [7].

The presence of aflatoxins requires warm temperatures and high humidity [13], such as in tropical, subtropical, and Mediterranean climates $[14,15]$. The date palm (Phoenix dactylifera L.) is a crop grown in these regions [16-18], and it is also cultivated in its preferred habitats in the Middle East, North Africa, and the Arabian Peninsula [19]. According to the database of the Food and Agriculture Organization of the United Nations [20], the lead dateproducing countries over the period of 2010 to 2019 were Egypt, Iran, Saudi Arabia, Algeria, Iraq, Pakistan, Sudan, United Arab Emirates, Oman, and Tunisia (Figure S1). Despite the importance of date fruits in these regions and also their significance for Muslims, particularly during the holy month of Ramadan [21], the consumption of dates has increased outside of production areas [22]. As a result, dates are the second dried fruits traded throughout the world after raisins due to their sweet taste and nutritive values [22]. Figures 1 and 2 reflect the demand for dates worldwide and the widespread consumption of dates based on data extracted from the International Trade Centre over the period of 2010 to 2019 [23].

Dates are rich in carbohydrates, some amino acids, and fiber, and they also contain significant amounts of vitamins and various minerals, particularly iron, potassium, calcium, and magnesium. Consequently, dates are among the most nourishing natural foods in the human diet [24]. However, dates also provide an ideal medium for toxigenic fungi growth and further aflatoxins contamination [16, 17, 22, 25]. Furthermore, dates are grown in climatic conditions that facilitate the toxigenic fungal invasion and aflatoxin formation $[16,17,22,26]$.

Such fungal invasion and the incidence of aflatoxins in date fruits have been investigated and confirmed in several countries, but with less attention compared with numerous publications on aflatoxins contamination in other agricultural commodities. The Food and Agriculture Organization (FAO) estimated the worldwide loss of dates in 2019 to be 1000 tonnes, excluding the losses that occurred before and during harvest [27]. Suhail et al. [28] investigated the postharvest losses of dates along the supply chain in Pakistan and found that the total losses of dates at the farm level were $29.6 \%$, compared with $41.33 \%$ and $35.33 \%$ at wholesale and retail levels, respectively. The results demonstrated that fungal attacks are one of the main reasons for date loss. Atia [29] reported that the most common fungi attributed to the loss of the dates is the Aspergillus species. Until now, the available data on the losses of this valuable food stuffs due to aflatoxin contamination has been limited.
Monitoring the occurrence of aflatoxins contamination in dates is crucial, as dates are often consumed directly without any further processing, which may result in direct exposure to aflatoxins and pose human health problems. Therefore, the purpose of the current review is to summarize the available data regarding aflatoxin occurrence and contamination levels in date fruits worldwide and to outline the analytical procedures used for aflatoxin determination in dates.

\section{Methodology}

2.1. Criteria Used to Select Articles. An electronic search was conducted in major databases including Web of Science, PubMed, and Google Scholar using "Aflatoxin * AND Dried fruits", "Aflatoxin * AND Date fruits", Aflatoxin * AND Date Palm and "Mycotoxin * AND Dried fruits" as keywords. The databases were screened for the period between 2010 and 2019 with English language. The electronic search identified 170 articles, of which 14 were found to be eligible for inclusion. The publications were evaluated through the title, abstract, and full text of papers to ensure that these studies covered levels of aflatoxins contamination in dates (Figure 3).

\section{Results}

3.1. Analytical Procedure for Aflatoxins Determination in Date Palm Fruits. The general trend in aflatoxins analysis is the performance of total aflatoxins $\left(\mathrm{AFB}_{1}, \mathrm{AFB}_{2}, \mathrm{AFG}_{1}\right.$, and $\mathrm{AFG}_{2}$ ) methods, which allow the analysis of a wide range of aflatoxins in a single run, using liquid chromatography coupled to mass spectrometry/mass (LC-MS/MS) technique [30-34]. In addition, high performance liquid chromatography (HPLC) equipped with fluorescence detection was used in six studies [21, 26, 35-38]. These studies used an immunoaffinity column (IAC) for clean-up. The Kobra cell and trifluoroacetic acid (TFA) were used as derivatisation to increase the detection sensitivity (Table 1). In the study of Hegazy and El Sayed [40], enzyme-linked immunosorbent assay (ELISA) method was used for quantified aflatoxins levels using aflatoxin test kits. Based on this review, acetonitrile followed by methanol were the main elements of the polar aqueous media used in the extraction of aflatoxins from date palm fruits (Table 1). The adequacy of different analytical procedures utilised to determine aflatoxins in date palm fruits in the current review was indicated by the method's sensitivity. Particularly, the determined limits of detections (LODs) of the method, apart from the studies of Ibrahim et al. [35] and Azaiez et al. $[31,34]$, were not reported. The LODs of the analytical procedure are presented in Table 1 . The reported LODs for aflatoxins ranged from 1 to $0.04 \mu \mathrm{g} / \mathrm{kg}, 0.03 \mu \mathrm{g} / \mathrm{kg}, 0.04 \mu \mathrm{g} /$ $\mathrm{kg}$, and $0.02 \mu \mathrm{g} / \mathrm{kg}$ for $\mathrm{AFB}_{1}, \mathrm{AFB}_{2}, \mathrm{AFG}_{1}$, and $\mathrm{AFG}_{2}$, respectively. These values are below all current aflatoxins legislation, thus revealing all determined aflatoxin levels that exceed the permissible limits of aflatoxin specified in different legislation (Table 2). 


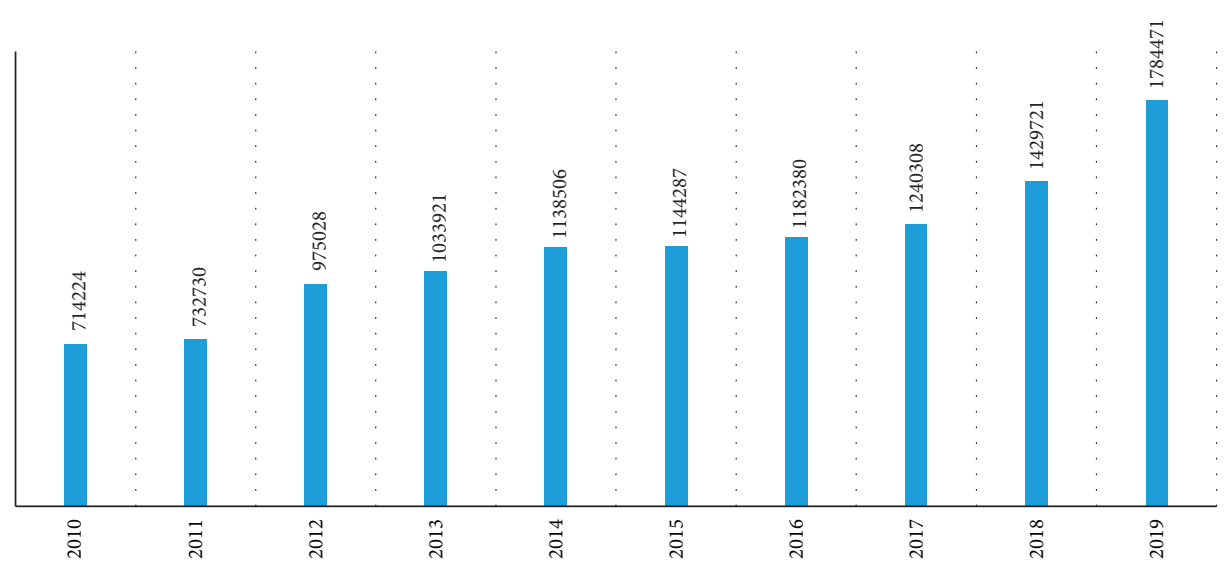

Figure 1: Dates global total import in tonnes for the period of 2010-2019. The data extracted from the International Trade Centre database [23].

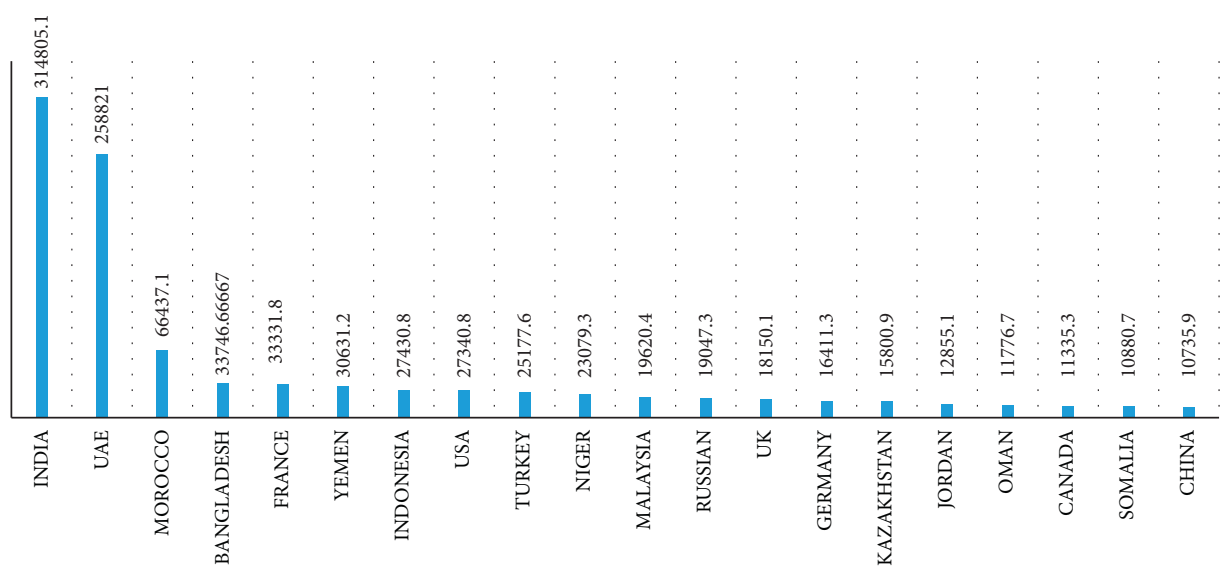

Figure 2: Dates global average import in tonnes by the highest importing countries of dates for the period of 2010-2019. The data extracted from the International Trade Centre database [23].

3.2. Levels and Incidence. The frequency and the incidence of aflatoxins contamination in dates in various world regions are presented in Table 3.

3.2.1. Asia. A number of studies have reported the occurrence of aflatoxins in dates in various regions in Pakistan. Iqbal et al. reported the incidence of $\mathrm{AFB}_{1}$ and total aflatoxins (AFs) in Punjab and Khyber Pakhtunkhwa in 2014 and 2018. The finding of 2014 study demonstrated that aflatoxins were detected in $39.6 \%$ of different date varieties, with an average of $2.13 \mu \mathrm{g} / \mathrm{kg}$ and $4.11 \mu \mathrm{g} / \mathrm{kg}$ for $\mathrm{AFB}_{1}$ and total AFs, respectively [21]. However, in 2018, a lower level of total AFs was found in dates with an average of $3.90 \mu \mathrm{g} / \mathrm{kg}$ [38]. Another investigation conducted in Khyber Pakhtunkhwa, Pakistan, detected aflatoxins in only $10 \%$ of samples, with an average of $2.5 \mu \mathrm{g} / \mathrm{kg}$ [39]. However, Masood et al. [36] have reported very high incidence rates in Khyber Pakhtunkhwa; that is, $60 \%$ date samples were contaminated with an average of $4.50 \mu \mathrm{g} / \mathrm{kg}$ and $6.32 \mu \mathrm{g} / \mathrm{kg}$ for $\mathrm{AFB}_{1}$ and total Afs, respectively. Over the period under review, the highest documented survey concerning aflatoxins contamination of dates was conducted in Pakistan from 2012 to 2015. Out of 170 collected samples, 25 were positive, with an average of $0.24 \mu \mathrm{g} / \mathrm{kg}$ for total Afs [26].

Aflatoxin contamination levels in Iranian dates were similar to the reported incidence in dates marketed in Riyadh, Saudi Arabia, where the mean concentration is about $2 \mu \mathrm{g} / \mathrm{kg}$ [35, 37], although higher frequency was documented in Saudi Arabia with $80 \%$ contamination. In Shanghai, China, none of Afs types were detected in all 40 samples of dates investigated by Han et al. [32].

3.2.2. Europe. In Europe, there were no aflatoxins detected in date samples collected from Valencia, Spain, and Perugia, Italy $[30,34]$. Additionally, the findings from the study of Azaiez et al. [31] reported that there was no incidence of aflatoxins contamination in various date varieties marketed in Spain. These samples were imported from various countries, namely, Tunisia, Israel, and Algeria.

3.2.3. Africa. Limited reports have been published regarding the incidence of aflatoxins contamination in dates in Africa. Hegazy and El Sayed [40] from Egypt investigated the 


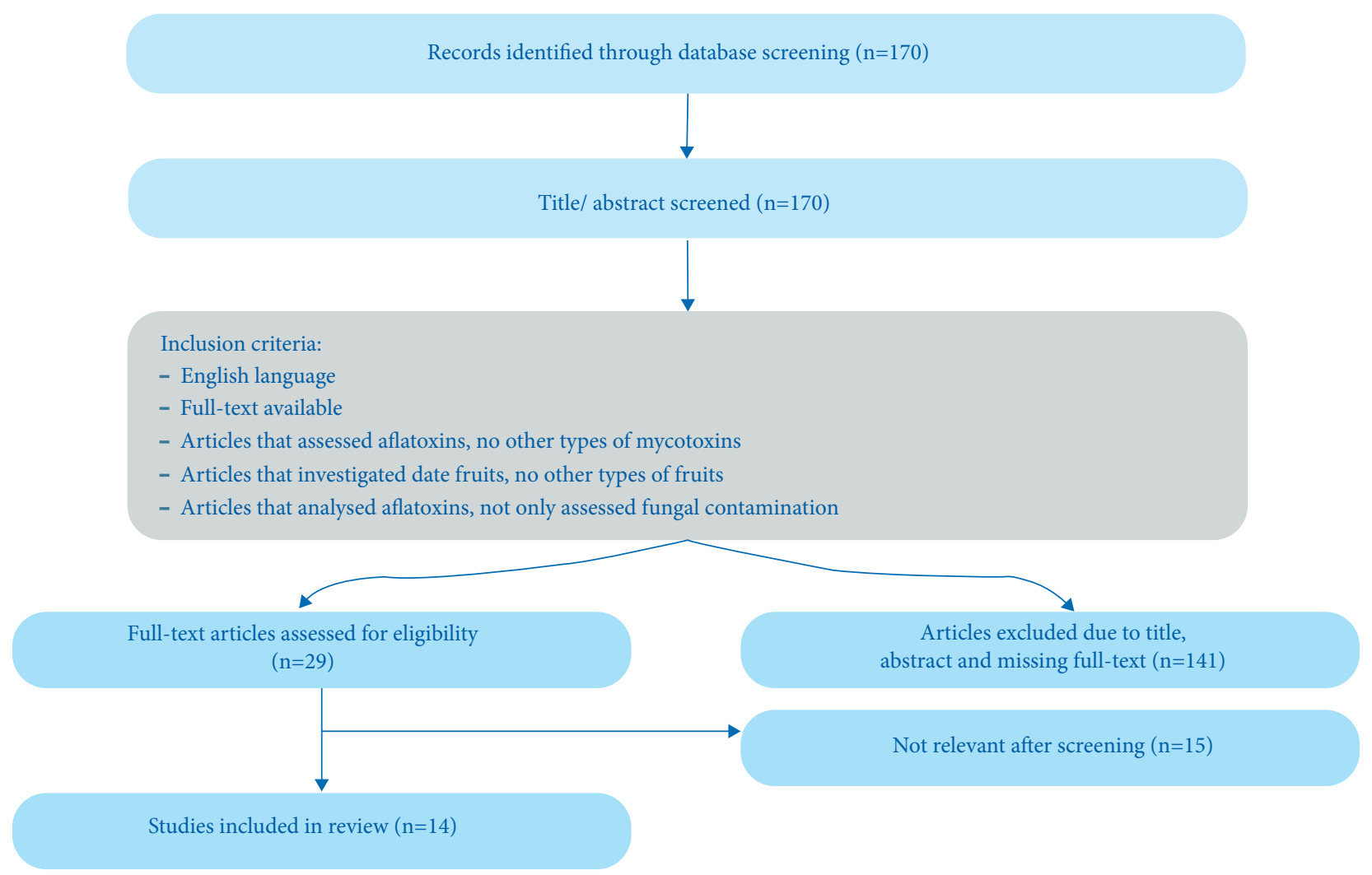

Figure 3: Flowchart indicating the search and selection process of articles.

presence of aflatoxins in dates (rutab and sukkary) and found that the samples were free from aflatoxins. The results are consistent with recent findings from Abdallah et al. [33], who found only one sample contaminated at levels of $14.4 \mu \mathrm{g} / \mathrm{kg}$ and $2.44 \mu \mathrm{g} / \mathrm{kg}$ for $\mathrm{AFB}_{1}$ and $\mathrm{AFB}_{2}$, respectively. In Tunisian markets, several date varieties ( 48 samples) were collected and analyzed; the average contamination levels of AFs in 22 positive samples were $1.14 \mu \mathrm{g} / \mathrm{kg}, 1.4 \mu \mathrm{g} / \mathrm{kg}$, and $1.7 \mu \mathrm{g} / \mathrm{kg}$ for $\mathrm{AFB}_{2}, \mathrm{AFG}_{1}$, and $\mathrm{AFG}_{2}$, respectively [31].

\section{Legal Limit}

In regulation terms, there is no harmonized regulation for aflatoxins on a global level $[44,45]$. However, aflatoxins are among the most important contaminates regulated by several countries and organizations to reduce the risk posed by these compounds to human health [46]. Table 2 presents a summary of the legal limits for aflatoxins in dried fruit according to the Gulf Standardization Organization, European Union member states, and the United States, compared with the studies reported the occurrence of aflatoxins in date palm fruits.

Over the period under review, in studies investigating the levels of aflatoxins contamination in dates in several parts of the world, the finding incidences were compared with the legislation of other international institutions and organizations, such as the European Commission (EC) and the US Food and Drug Administration (FDA). For example, studies conducted in Pakistan indicated that there is no regulation for maximum acceptable levels of aflatoxins in dry fruits; thus, the incidence of aflatoxins contaminated dates was compared with the recommended EC limits for $\mathrm{AFB}_{1}$ and total Afs, respectively [38].

\section{Discussion}

Dates are among the oldest cultivated fruits in the world and are mentioned in the holy texts of Judaism, Christianity, and Islam. Dates thus have religious and cultural values in addition to their nutritive values [47]. Dates consumption is not limited to date production areas [21], and the last ten years have seen a dramatic increase in date imports globally (Figure 1) [23]. Thus, dates are one of the most traded commodities worldwide. Recently, the Food and Agriculture Organization (FAO) approved a request from Saudi Arabia to designate 2027 as the International Year of Dates. The request was initiated because of the Earth's changing climate and the potential effects on global food security; dates represent a sustainable agricultural commodity grown under various climatic conditions [47].

Consequently, monitoring the safety of date fruits regarding aflatoxins contamination is considerably important due to the health risks associated with human exposure to aflatoxins. In this context, strict adherence to guidelines to minimise toxigenic fungi growth and further aflatoxins contamination should be implemented. These guidelines include good agricultural practices during production, good hygienic practices during postharvest handling, and good manufacturing practices during processing [48]. Recently, the use of nanotechnology innovations has been reported to be an 
TABLE 1: Analytical procedure for aflatoxins determination in date palm fruits.

\begin{tabular}{|c|c|c|c|c|c|c|c|c|c|}
\hline \multirow[t]{2}{*}{ Country } & \multirow[t]{2}{*}{ Tech } & \multirow[t]{2}{*}{ Derivatization } & \multirow[t]{2}{*}{ Extraction } & \multirow[t]{2}{*}{ Clean-up } & \multicolumn{4}{|c|}{$\begin{array}{l}\text { Limit of detection } \mu \mathrm{g} / \\
\mathrm{kg}\end{array}$} & \multirow[t]{2}{*}{ Reference } \\
\hline & & & & & $\mathrm{B}_{1}$ & $\mathrm{~B}_{2}$ & $\mathrm{G}_{1}$ & $\mathrm{G}_{2}$ & \\
\hline $\begin{array}{l}\text { Pakistan (Khyber } \\
\text { Pakhtunkhwa) }\end{array}$ & $\mathrm{LC}$ & TFA & Methanol: water & $\begin{array}{l}\text { Immunoaffinity } \\
\text { column }\end{array}$ & 0.5 & 1.0 & 0.5 & 1.0 & [39] \\
\hline Saudi Arabia (Riyadh) & HPLC & PBPB & Methanol: water & $\begin{array}{l}\text { Immunoaffinity } \\
\text { column }\end{array}$ & - & - & - & - & {$[35]$} \\
\hline $\begin{array}{l}\text { Pakistan (Punjab and Khyber } \\
\text { Pakhtunkhwa) }\end{array}$ & HPLC & TFA & Acetonitrile: water & $\begin{array}{l}\text { Immunoaffinity } \\
\text { column }\end{array}$ & 0.05 & 0.06 & 0.05 & 0.06 & {$[21]$} \\
\hline Egypt (Cairo) & ELISA & - & Methanol: water & - & \multicolumn{4}{|c|}{1.0} & {$[40]$} \\
\hline Spain (Valencia) & $\begin{array}{l}\text { LC-MS/ } \\
\text { MS }\end{array}$ & - & $\begin{array}{l}\text { Acetonitrile: water: } \\
\text { acetic acid }\end{array}$ & - & 0.08 & 0.08 & 0.16 & 0.3 & {$[30]$} \\
\hline $\begin{array}{l}\text { Pakistan (Khyber } \\
\text { Pakhtunkhwa) }\end{array}$ & HPLC & TFA & Acetonitrile: water & $\begin{array}{l}\text { Immunoaffinity } \\
\text { column }\end{array}$ & 0.04 & 0.07 & 0.04 & 0.07 & {$[36]$} \\
\hline Spain (Valencia) & $\begin{array}{l}\text { LC-MS/ } \\
\text { MS }\end{array}$ & - & $\begin{array}{l}\text { Acetonitrile: water: } \\
\text { acetic acid }\end{array}$ & - & - & - & - & - & {$[31]$} \\
\hline Tunisia (Tunis) & $\begin{array}{l}\text { LC-MS/ } \\
\text { MS }\end{array}$ & - & $\begin{array}{l}\text { Acetonitrile: water: } \\
\text { acetic acid }\end{array}$ & - & - & - & - & - & {$[31]$} \\
\hline China (Shanghai) & $\begin{array}{l}\text { LC-MS/ } \\
\text { MS }\end{array}$ & - & Acetonitrile: water & - & 0.1 & 0.1 & 0.3 & 0.3 & {$[32]$} \\
\hline $\begin{array}{l}\text { Pakistan (different areas of } \\
\text { Pakistan) }\end{array}$ & HPLC & Kobra Cell $^{\mathrm{TM}}$ & Methanol: water & $\begin{array}{l}\text { Immunoaffinity } \\
\text { column }\end{array}$ & \multicolumn{4}{|c|}{0.12} & {$[26]$} \\
\hline Iran (Hamadan) & HPLC & - & Methanol: water & $\begin{array}{l}\text { Immunoaffinity } \\
\text { column }\end{array}$ & 0.06 & 0.05 & 0.08 & 0.02 & {$[37]$} \\
\hline $\begin{array}{l}\text { Pakistan (Punjab and Khyber } \\
\text { Pakhtunkhwa) }\end{array}$ & HPLC & TFA & Acetonitrile: water & $\begin{array}{l}\text { Immunoaffinity } \\
\text { column }\end{array}$ & 0.04 & 0.07 & 0.04 & 0.07 & {$[38]$} \\
\hline Egypt (Assiut) & $\begin{array}{l}\text { LC-MS/ } \\
\text { MS }\end{array}$ & - & $\begin{array}{l}\text { Acetonitrile: water: } \\
\text { acetic acid }\end{array}$ & - & 0.05 & 0.03 & - & - & {$[33]$} \\
\hline Italy (Perugia) & $\begin{array}{l}\text { LC-MS/ } \\
\text { MS }\end{array}$ & - & $\begin{array}{l}\text { Acetonitrile: water: } \\
\text { acetic acid }\end{array}$ & - & - & - & - & - & {$[34]$} \\
\hline
\end{tabular}

LC-MS/MS: liquid chromatography with tandem mass spectrometry; HPLC: high performance liquid chromatography; ELISA: enzyme-linked immunosorbent assay; TFA: trifluoroacetic acid; PBPB: pyridinium hydrobromide perbromide.

effective technique for preserving date palms. For example, the use of edible films and coatings made from chitosan nanoparticles as antifungal materials has been proven to improve the storability of fruits, including date palms $[49,50]$.

The review shows the different analytical procedures (LC, HPLC, LC-MS/MS, and ELISA) utilised to determine the levels of the four targeted analytes $\left(\mathrm{AFB}_{1}, \mathrm{AFG}_{1}, \mathrm{AFB}_{2}\right.$, and $A F G_{2}$ ) in date palm fruits (Table 1). To detect and quantify aflatoxins without matrix interference from the investigated foodstuff, the toxins should be extracted from the samples and cleaned up, whether chromatography or immunoassay techniques were applied [51]. In the current review, the least common methods of analysis for aflatoxins used were LC and ELISA. Chromatographic methods are among the older analytical techniques used for this purpose. These methods include the LC technique, which is highly sensitive but slower than other methods [52]. On the other hand, ELISA for the analysis of aflatoxins is considered an alternative immunochemical approach to chromatography analysis due to its rapidity, simplicity, and sensitivity. These features are attributed to antibody-antigen interactions, but one of the possible drawbacks of the ELISA technique is its cross-reactivity towards other related toxins [53]. Currently, the combination of LC with fluorescence detection (LC-FD) or with mass spectrometry (LC-MS) or with tandem mass spectrometry (LC-MS/MS) are the most used methods for the quantification of aflatoxins [7]. In the case of the LC-FD method, samples are commonly extracted with methanol or mixtures of methanol and water. Then, an immunoaffinity column (IAC) can be used for clean-up before separation with LC, post-column derivatization, and quantification by FD. Unlike LC-FD, LC-MS and LC-MS/MS do not require derivatisation. For analysis using LC-MS or LC-MS/MS techniques, the samples are commonly extracted with acetonitrile and sometimes in mixtures with water or formic acid before analysis. Nowadays, LC-MS/MS have gained a great popularity and have been widely applied in aflatoxins analysis due to their suitability for multiple toxins detection in a single run with high reliability and sensitivity [7, 54, 55].

As shown in Table 1, the reported LODs varied according to the diversity of the techniques utilised. However, the indicated LODs of the methods were significantly below the legal limit set by the FDA in the USA, the EU in the European Union, and the GSO in the Gulf States (Table 2). Therefore, it can identify aflatoxins in the investigated date palm fruits that do not comply with current aflatoxins legislation. The susceptibility of dates to aflatoxins contamination over the period under review has been documented at various levels in different world regions. In general, the occurrence of aflatoxins in date fruits was frequently investigated in Pakistan. This could be explained by the fact that Pakistan is one of the major producers of date fruits. On the other hand, no or limited 
TABLE 2: Legal limits for aflatoxins of dried fruit in gulf standardization organization, European Union member states, and the United States, compared with the studies reporting the occurrence of aflatoxins in date palm fruits.

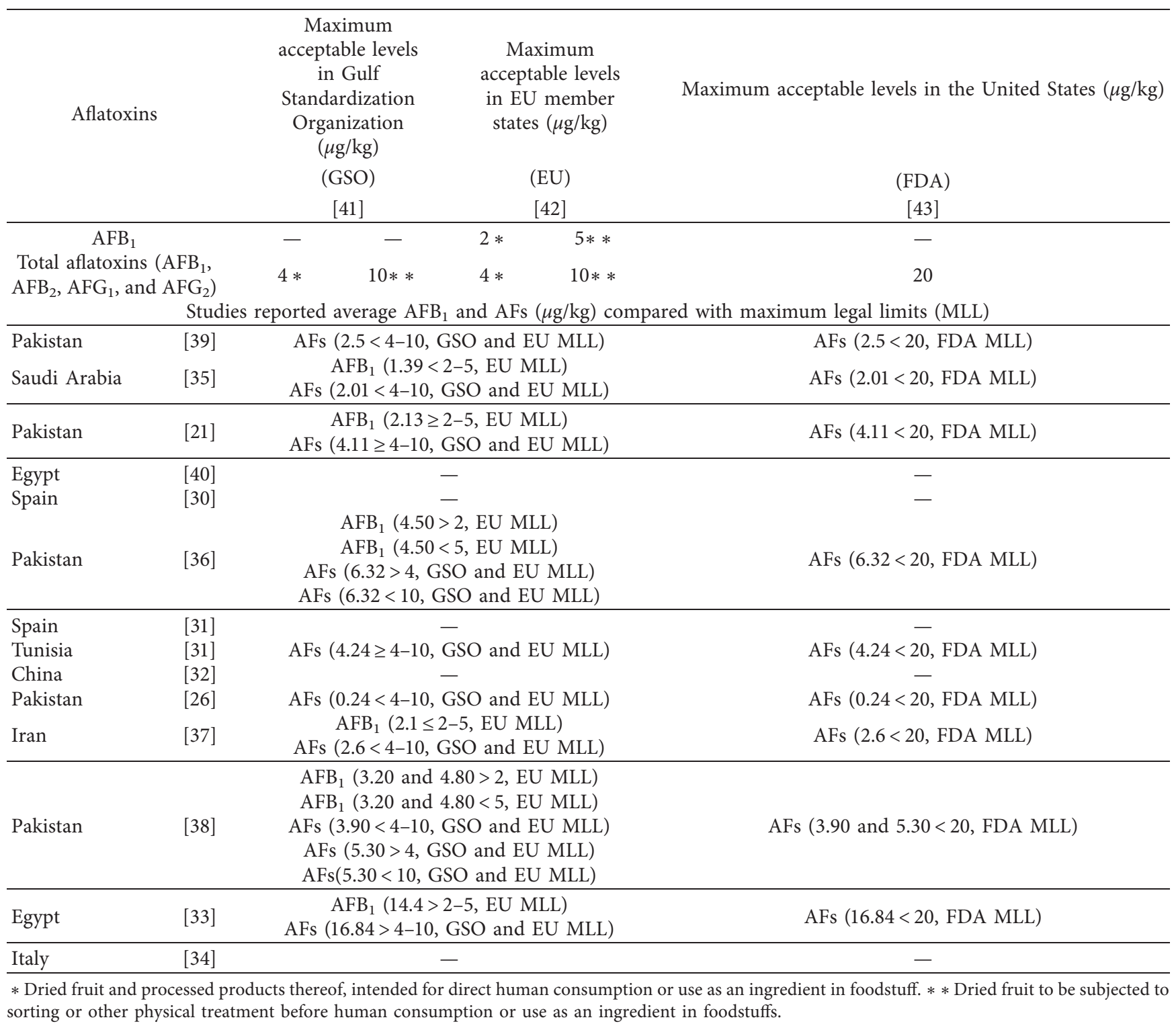

information exist regarding the levels and incidence of aflatoxins in dates from other producers countries, such as Egypt, Saudi Arabia, and Iraq, where dates are highly produced and consumed $[19,22]$. The highest documented level of aflatoxins contamination in dates was $26.60 \mu \mathrm{g} / \mathrm{kg}$ among $42.9 \%$ positive samples collected from southern areas of Punjab and Khyber Pakhtunkhwa, Pakistan [21]. This level is above the legal limits in the EU for $\mathrm{AFB}_{1}$ and total AFs ( 2 and $4 \mu \mathrm{g} / \mathrm{kg}$, resp.) and exceeds the maximum acceptable level in FDA regulation for total AFs $(20 \mu \mathrm{g} / \mathrm{kg}$ ) (Table 2). In Europe, no incidence of aflatoxins contamination in dates has been reported. This finding could be due to the restrictive regulations for permissible limits for aflatoxins in food, in addition to the availability of effective safety systems, for example, the Rapid Alert System for Food and Feed (RASFF) of the European Union, which seeks to protect human health from food and feed-related risks [56]. Williams et al. [10] commented that the least polluted foodstuff is exported to the developed countries, and the most polluted foodstuff is retained back home to be consumed by the local population in developing countries. Thus, the potential risk of human exposure to aflatoxin varies on a global scale.

Heshmati et al. [37] investigated the potential risk of human exposure to aflatoxins in Iran. The results demonstrated that the estimated average daily dietary exposure to $\mathrm{AFB}_{1}$ from dates consumption was $0.12 \mathrm{ng} / \mathrm{kg}$ bw/day compared with 0.04 , 0.04 , and $0.06 \mathrm{ng} / \mathrm{kg} \mathrm{bw/day} \mathrm{for} \mathrm{mulberries,} \mathrm{figs,} \mathrm{and} \mathrm{apricots,}$ respectively. In other words, the estimated $\mathrm{AFB}_{1}$ intake from dates consumption was higher than that for other dried fruit. This indicates the fact that the dates can be a likely contributor to the dietary intake of aflatoxins. However, the data available on the contamination of dates by aflatoxins is limited because dates are less frequently investigated compared with other types of foodstuffs. 
TABLE 3: The frequency and the incidence of aflatoxins contamination in dates in various world regions.

\begin{tabular}{|c|c|c|c|c|c|}
\hline Country & $\begin{array}{c}\text { No. of samples/contaminated } \\
\text { samples }\end{array}$ & Aflatoxins & $\begin{array}{l}\text { Average }(\mu \mathrm{g} / \\
\mathrm{kg})\end{array}$ & $\begin{array}{c}\text { Range of contamination } \\
(\mu \mathrm{g} / \mathrm{kg})\end{array}$ & Reference \\
\hline Pakistan (Khyber Pakhtunkhwa) & $20 / 2$ (dried dates) & Total AFs & 2.5 & $2.1-2.9$ & [39] \\
\hline Saudi Arabia (Riyadh) & $12 / 10$ (Semi-dry dates) & $\begin{array}{c}\mathrm{AFB}_{1} \\
\text { Total AFs }\end{array}$ & $\begin{array}{l}1.39 \pm 1.42 \\
2.01 \pm 1.76\end{array}$ & 0.00 to 5.92 & {$[35]$} \\
\hline $\begin{array}{l}\text { Pakistan (Punjab and Khyber } \\
\text { Pakhtunkhwa) }\end{array}$ & 96/38 (different date varieties) & $\begin{array}{c}\text { AFB }_{1} \\
\text { Total AFs }\end{array}$ & $\begin{array}{l}2.13 \pm 0.62 \\
4.11 \pm 0.80 \\
\end{array}$ & LOD-26.60 & {$[21]$} \\
\hline $\begin{array}{l}\text { Egypt (Cairo) } \\
\text { Spain (Valencia) }\end{array}$ & $\begin{array}{l}5 / 0 \text { (rutab and sukkary) } \\
3 / 0 \text { (dried dates) }\end{array}$ & $\begin{array}{l}\text { Total AFs } \\
\text { Total AFs }\end{array}$ & $\begin{array}{l}\text { Abs } \\
\text { Abs }\end{array}$ & $\begin{array}{l}\text { Abs } \\
\text { Abs }\end{array}$ & $\begin{array}{l}{[40]} \\
{[30]}\end{array}$ \\
\hline Pakistan (Khyber Pakhtunkhwa) & $15 / 9$ (dried dates) & $\begin{array}{l}\mathrm{AFB}_{1} \\
\text { Total AFs }\end{array}$ & $\begin{array}{l}4.50 \pm 0.46 \\
6.32 \pm 0.78\end{array}$ & $\begin{array}{c}\text { LOD-9.80 } \\
\text { LOD-18.79 }\end{array}$ & {$[36]$} \\
\hline Spain (Valencia) & 27/0 (different date varieties) & $\begin{array}{l}\text { Total AFs } \\
\text { AFB }_{1}\end{array}$ & $\begin{array}{l}\text { Abs } \\
\text { n.d. }\end{array}$ & $\begin{array}{l}\text { Abs } \\
\text { Abs }\end{array}$ & {$[31]$} \\
\hline Tunisia (Tunis) & 48/22 (different date varieties) & $\begin{array}{l}\mathrm{AFB}_{2} \\
\mathrm{AFG}_{1} \\
\mathrm{AFG}_{2}\end{array}$ & $\begin{array}{c}1.14 \\
1.4 \\
1.7 \\
\end{array}$ & $\begin{array}{c}1.1-1.3 \\
\text { LOQ-1.8 } \\
\text { LOQ- } 2.2\end{array}$ & {$[31]$} \\
\hline China (Shanghai) & $40 / 0$ (dried dates) & Total AFs & Abs & Abs & {$[32]$} \\
\hline $\begin{array}{l}\text { Pakistan (different areas of } \\
\text { Pakistan) }\end{array}$ & $170 / 25$ (dried dates) & Total AFs & $0.24 \pm 0.08$ & $0.24-5.87$ & {$[26]$} \\
\hline Iran (Hamadan) & $22 / 9$ (dried dates) & $\begin{array}{l}\mathrm{AFB}_{1} \\
\text { Total AFs }\end{array}$ & $\begin{array}{l}2.1 \pm 1.8 \\
2.6 \pm 2.3\end{array}$ & $\begin{array}{c}0.6-6 \\
0.9-8.1 \\
\end{array}$ & [37] \\
\hline $\begin{array}{l}\text { Pakistan (Punjab and Khyber } \\
\text { Pakhtunkhwa) }\end{array}$ & $17 / 5$ (dried dates) & $\begin{array}{c}\mathrm{AFB}_{1} \\
\text { Total AFs } \\
\mathrm{AFB}_{1} \\
\text { Total AFs }\end{array}$ & $\begin{array}{l}4.80 \pm 0.95 \\
5.30 \pm 1.80 \\
3.20 \pm 0.90 \\
3.90 \pm 0.95\end{array}$ & LOD-15.50 & {$[38]$} \\
\hline Egypt (Assiut) & 28/1 (dried dates) & $\begin{array}{l}\mathrm{AFB}_{1} \\
\mathrm{AFB}_{2}\end{array}$ & $\begin{array}{l}\text { Abs } \\
\text { Abs }\end{array}$ & $\begin{array}{l}14.4 \\
2.44 \\
\end{array}$ & [33] \\
\hline Italy (Perugia) & 20/0 (dried dates) & Total AFs & Abs & Abs & {$[34]$} \\
\hline
\end{tabular}

LOD: limit of detection. LOQ: limit of quantification. n.d.: not detectable. Abs: absent.

As stated earlier, the recent risk assessment of aflatoxins by the EFSA reported that, among all types of aflatoxins, $\mathrm{AFB}_{1}$ was the most frequent contaminant detected in food, and the importance of continuously monitoring the occurrence of aflatoxins is emphasised due to the Earth's changing climate and its impact on the increased risk of aflatoxins contamination [7]. Consequently, the risk of human exposure to this carcinogenic component increases and it is classified as a Group 1 carcinogen based on strong evidence of its genotoxicity, which results in the formation of DNA adducts causing point mutations in the TP53 gene [12]. This situation raises concerns regarding the risk of human exposure to aflatoxins through the consumption of dates especially in date-producing regions, such as the Middle East, North Africa and the Arabian Peninsula, where dates are considered as a staple food by the majority $[19,22]$.

\section{Conclusion}

In conclusion, the current review has presented and discussed the available data regarding the levels and incidence of aflatoxins in dates worldwide, for the first time. This information has clear implications regarding the importance of monitoring aflatoxins contamination in dates. Moreover, the review has highlighted the lack of related data, as the situation is unclear for most regions. Thus, it is important to conduct more comprehensive studies for the occurrence and contamination levels of aflatoxins in dates.

\section{Data Availability}

The data that support the findings of this study are included within the supplementary information file.

\section{Conflicts of Interest}

The author declares no conflicts of interest.

\section{Supplementary Materials}

The following is available online at https://.xxx/s1. Figure S1: dates global average production in tonnes by counties for the period of 2010-2019. (Supplementary Materials)

\section{References}

[1] A. Medina, A. Rodriguez, and N. Magan, "Effect of climate change on Aspergillus flavus and aflatoxin B1 production," Frontiers in Microbiology, vol. 5, p. 348, 2014.

[2] M. Adhikari, E. L. Isaac, R. R. M. Paterson, and M. A. Maslin, "A review of potential impacts of climate change on coffee cultivation and mycotoxigenic fungi," Microorganisms, vol. 8, no. 10, p. 1625, 2020.

[3] D. Khodaei, F. Javanmardi, and A. M. Khaneghah, "The global overview of the occurrence of mycotoxins in cereals: a threeyear survey," Current Opinion in Food Science, vol. 39, 2020.

[4] R. B. Mulaudzi, "Mycotoxins of medicinal plants and human health," in Encyclopedia of Environmental Health, J. Nriagu, Ed., pp. 524-530, Elsevier, Oxford, UK, Second edition, 2019. 
[5] M. Tajkarimi, M. H. Shojaee, H. Yazdanpanah, and S. A. Ibrahim, "Aflatoxin in agricultural commodities and herbal medicine," in Aflatoxins -Biochemistry and Molecular Biology, R. G. González, Ed., pp. 367-394, InTech, London, UK, 2011.

[6] B. R. Rushing and M. I. Selim, "Aflatoxin B1: a review on metabolism, toxicity, occurrence in food, occupational exposure, and detoxification methods," Food and Chemical Toxicology, vol. 124, pp. 81-100, 2019.

[7] European Food Safety Authority, "Risk assessment of aflatoxins in food," EFSA Journal, vol. 18, Article ID e06040, 2020.

[8] D. L. Eaton and E. P. Gallagher, "Mechanisms of aflatoxin carcinogenesis," Annual Review of Pharmacology and Toxicology, vol. 34, no. 1, pp. 135-172, 1994.

[9] K. De Ruyck, M. De Boevre, I. Huybrechts, and S. De Saeger, "Dietary mycotoxins, co-exposure, and carcinogenesis in humans: short review," Mutation Research/Reviews in $\mathrm{Mu}$ tation Research, vol. 766, pp. 32-41, 2015.

[10] J. H. Williams, T. D. Phillips, P. E. Jolly, J. K. Stiles, C. M. Jolly, and D. Aggarwal, "Human aflatoxicosis in developing countries: a review of toxicology, exposure, potential health consequences, and interventions," The American Journal of Clinical Nutrition, vol. 80, no. 5, pp. 1106-1122, 2004.

[11] P. A. Murphy, S. Hendrich, C. Landgren, and C. M. Bryant, "Food mycotoxins: an update," Journal of Food Science, vol. 71, no. 5, pp. R51-R65, 2006.

[12] International Agency for Research on Cancer, "A review of human carcinogens: chemical agents and related occupations," in IARC Monographs on the Evaluation of Carcinogenic Risks to Humans, Vol. 100 F, IARC, Lyon, France, 2012.

[13] G. S. Bbosa, D. Kitya, A. Lubega, J. Ogwal-Okeng, W. W. Anokbonggo, and D. B. Kyegombe, "Review of the biological and health effects of aflatoxins on body organs and body systems," Aflatoxins-Recent Advances and Future Prospects, vol. 12, pp. 239-265, 2013.

[14] J. I. Pitt and A. D. Hocking, Fungi and Food Spoilage, Springer, Berlin, Germany, 2009.

[15] P. Battilani, P. Toscano, H. J. van der Fels-Klerx et al., "Aflatoxin B1 contamination in maize in Europe increases due to climate change," Scientific Reports, vol. 6, pp. 24328-24337, 2016.

[16] I. A. Ahmed, A. W. K. Ahmed, and R. K. Robinson, "Susceptibility of date fruits (Phoenix dactylifera) to aflatoxin production," Journal of the Science of Food and Agriculture, vol. 74, no. 1, pp. 64-68, 1997.

[17] M. Shenasi, K. E. Aidoo, and A. A. G. Candlish, "Microflora of date fruits and production of aflatoxins at various stages of maturation," International Journal of Food Microbiology, vol. 79, no. 1-2, pp. 113-119, 2002.

[18] H. Karaca and S. Nas, "Aflatoxins, patulin and ergosterol contents of dried figs in Turkey," Food Additives and Contaminants, vol. 23, no. 5, pp. 502-508, 2006.

[19] C. T. Chao and R. R. Krueger, "The date palm (Phoenix dactylifera L.): overview of biology, uses, and cultivation," HortScience, vol. 42, no. 5, pp. 1077-1082, 2007.

[20] Food and Agriculture Organization, "Faostat," 2021, https:// www.fao.org/faostat/en/\#data/FBS.

[21] S. Z. Iqbal, M. R. Asi, and S. Jinap, "Aflatoxins in dates and dates products,” Food Control, vol. 43, pp. 163-166, 2014.

[22] H. Ozer, H. I. Oktay Basegmez, and G. Ozay, "Mycotoxin risks and toxigenic fungi in date, prune and dried apricot among mediterranean crops," Phytopathologia Mediterranea, vol. 51, pp. 148-157, 2012.

[23] International Trade Centre, "International trade statistics," 2019, https://www.trademap.org/Country_SelProduct_TS. aspx?nvpm $=1 \% 7 \mathrm{c} \% 7 \mathrm{c} \% 7 \mathrm{c} \% 7 \mathrm{c} \% 7 \mathrm{c} 080410 \% 7 \mathrm{c} \% 7 \mathrm{c} \% 7 \mathrm{c} 6 \%$ $7 \mathrm{c} 1 \% 7 \mathrm{c} 1 \% 7 \mathrm{c} 1 \% 7 \mathrm{c} 2 \% 7 \mathrm{c} 1 \% 7 \mathrm{c} 2 \% 7 \mathrm{c} 1 \% 7 \mathrm{c} \% 7 \mathrm{c} 1$.

[24] R. M. A. Mohamed, A. S. M. Fageer, M. M. Eltayeb, and I. A. Mohamed Ahmed, "Chemical composition, antioxidant capacity, and mineral extractability of S udanese date palm (Hoenix dactylifera L.) fruits," Food Science \& Nutrition, vol. 2, no. 5, pp. 478-489, 2014.

[25] Y. A. Gherbawy, H. M. Elhariry, and A. A. S. Bahobial, "Mycobiota and mycotoxins (aflatoxins and ochratoxin) associated with some saudi date palm fruits," Foodborne Pathogens and Disease, vol. 9, no. 6, pp. 561-567, 2012.

[26] M. A. Asghar, A. Ahmed, E. Zahir, M. A. Asghar, J. Iqbal, and G. Walker, "Incidence of aflatoxins contamination in dry fruits and edible nuts collected from Pakistan," Food Control, vol. 78, pp. 169-175, 2017.

[27] Food and Agriculture Orgnization, "Faostat," 2021, https:// www.fao.org/faostat/en/\#data/QC.

[28] M. Suhail, Y. Durrani, M. S. Hashmi et al., "Postharvest losses of dhakki dates during supply chain in Pakistan," Fresenius Environmental Bulletin, vol. 29, pp. 299-309, 2020.

[29] M. Atia, "Efficiency of physical treatments and essential oils in controlling fungi associated with some stored date palm fruits," Australin Journal of Basic Application Science, vol. 5, pp. 1572-1580, 2011.

[30] I. Azaiez, F. Giusti, G. Sagratini, J. Mañes, and M. FernándezFranzón, "Multi-mycotoxins analysis in dried fruit by LC/MS/ MS and a modified QuEChERS procedure," Food Analytical Methods, vol. 7, no. 4, pp. 935-945, 2014.

[31] I. Azaiez, G. Font, J. mañes, and M. Fernández-Franzón, "Survey of mycotoxins in dates and dried fruits from Tunisian and Spanish markets," Food Control, vol. 51, pp. 340-346, 2015.

[32] Z. Han, M. Dong, W. Han et al., "Occurrence and exposure assessment of multiple mycotoxins in dried fruits based on liquid chromatography-tandem mass spectrometry," World Mycotoxin Journal, vol. 9, no. 3, pp. 465-474, 2016.

[33] M. F. Abdallah, R. Krska, and M. Sulyok, "Occurrence of ochratoxins, fumonisin b2, aflatoxins (B1and B2), and other secondary fungal metabolites in dried date palm fruits from Egypt: a mini-survey," Journal of Food Science, vol. 83, no. 2, pp. 559-564, 2018.

[34] M. Quaglia, M. Santinelli, M. Sulyok, A. Onofri, L. Covarelli, and G. Beccari, "Aspergillus, Penicillium and Cladosporium species associated with dried date fruits collected in the Perugia (Umbria, Central Italy) market," International Journal of Food Microbiology, vol. 322, Article ID 108585, 2020.

[35] M. Ibrahim, H. Ali, A. Sahab, and A. Al-Khalifa, "Co-occurrence of fungi, aflatoxins, ochratoxins a and fumonsins in date palm fruits of Saudi Arabia," Journal of Applied Sciences Research, vol. 9, pp. 1449-1456, 2013.

[36] M. Masood, S. Z. Iqbal, M. R. Asi, and N. Malik, "Natural occurrence of aflatoxins in dry fruits and edible nuts," Food Control, vol. 55, pp. 62-65, 2015.

[37] A. Heshmati, T. Zohrevand, A. M. Khaneghah, A. S. Mozaffari Nejad, and A. S. Sant'Ana, "Co-occurrence of aflatoxins and ochratoxin a in dried fruits in Iran: dietary exposure risk assessment," Food and Chemical Toxicology, vol. 106, pp. 202-208, 2017.

[38] S. Z. Iqbal, Z. Mehmood, M. R. Asi, M. Shahid, M. Sehar, and N. Malik, "Co-occurrence of aflatoxins and ochratoxin a in nuts, dry fruits, and nuty products," Journal of Food Safety, vol. 38, no. 4, Article ID e12462, 2018.

[39] G. Luttfullah and A. Hussain, "Studies on contamination level of aflatoxins in some dried fruits and nuts of Pakistan," Food Control, vol. 22, no. 3-4, pp. 426-429, 2011. 
[40] E. M. Hegazy and H. Z. El Sayed, "Chemical, physical properties and aflatoxins content of palm date fruit sprinkled with some spices and herbs," World Applied Sciences Journal, vol. 32, pp. 2375-2381, 2014.

[41] Standardization Organization of the Cooperation Council for the Arab States of the Gulf, "General standard for contaminants \& toxins in food," 2019, https://members.wto.org/ crnattachments/2019/SPS/SAU/19_2109_00_e.pdf.

[42] European Commission, "Commission regulation (EC) No. 165/2010 of 26 february 2010," Official Journal of the European Union, vol. 50, 2010.

[43] Food and Drug Administration, "Guidance for industry: action levels for poisonous or deleterious substances in human food and animal feed," 2018, https://www.fda.gov/ regulatory-information/search-fda-guidance-documents/ guidance-industry-action-levels-poisonous-or-deleterioussubstances-human-food-and-animal-feed\#afla.

[44] C. Cucci, A. G. Mignani, C. Dall'Asta, R. Pela, and A. Dossena, "A portable fluorometer for the rapid screening of M1 aflatoxin," Sensors and Actuators B: Chemical, vol. 126, no. 2, pp. 467-472, 2007.

[45] Z. Ráduly, L. Szabó, A. Madar, I. Pócsi, and L. Csernoch, "Toxicological and medical aspects of Aspergillus-derived Mycotoxins entering the feed and food chain," Frontiers in Microbiology, vol. 10, p. 2908, 2020.

[46] World Health Organization, “Aflatoxins," 2018, https://www. who.int/foodsafety/FSDigest_Aflatoxins_EN.pdf.

[47] Food and Agriculture Orgnization, "Committee on agriculture," 2020, https://www.fao.org/3/nd415en/nd415en.pdf.

[48] A. A. Kader and A. M. Hussein, "Harvesting and postharvest handling of dates," ICARDA, Aleppo, Syria, vol. 4, p. 15, 2009.

[49] S. Kumar, A. Mukherjee, and J. Dutta, "Chitosan based nanocomposite films and coatings: emerging antimicrobial food packaging alternatives," Trends in Food Science \& Technology, vol. 97, pp. 196-209, 2020.

[50] M. Sarraf, M. Jemni, I. Kahramanoğlu et al., "Commercial techniques for preserving date palm (Phoenix dactylifera) fruit quality and safety: a review," Saudi Journal of Biological Sciences, vol. 28, pp. 4408-4420, 2021.

[51] R. Krska, P. Schubert-Ullrich, A. Molinelli, M. Sulyok, S. Macdonald, and C. Crews, "Mycotoxin analysis: an update," Food Additives \& Contaminants: Part A, vol. 25, no. 2, pp. 152-163, 2008.

[52] M. Mahfuz, M. A. Gazi, M. Hossain, M. R. Islam, S. M. Fahim, and T. Ahmed, "General and advanced methods for the detection and measurement of aflatoxins and aflatoxin metabolites: a review," Toxin Reviews, vol. 39, 2018.

[53] A. Pal, D. Acharya, D. Saha, and T. K. Dhar, "Development of a membrane-based immunofiltration assay for the detection of T-2 toxin," Analytical Chemistry, vol. 76, no. 14, pp. 4237-4240, 2004.

[54] S. Y. Woo, S. Y. Ryu, F. Tian, S. Y. Lee, S. B. Park, and H. S. Chun, "Simultaneous determination of twenty mycotoxins in the Korean soybean paste doenjang by LC-MS/MS with immunoaffinity cleanup," Toxins, vol. 11, no. 10, p. 594, 2019.

[55] A. Ouakhssase, A. Chahid, H. Choubbane, A. Aitmazirt, and E. A. Addi, "Optimization and validation of a liquid chromatography/tandem mass spectrometry (LC-MS/MS) method for the determination of aflatoxins in maize," Heliyon, vol. 5, no. 5, Article ID e01565, 2019.

[56] The Rapid Alert System for Food And Feed, "RASFF- food and feed safety alerts," 2020, https://ec.europa.eu/food/safety/ rasff_en. 